\title{
Tindak Tutur Kesantunan Guru dan Siswa dalam Pembelajaran Bahasa Indonesia di SMP Negeri 2 Sakra: Tinjauan Pragmatik
}

\author{
Badelah $^{1}$, Mahsun ${ }^{2} \&$ Burhanuddin ${ }^{3}$ \\ Magister Pendidikan Bahasa Indonesia Universitas Mataram \\ Jl. Majapahit no.62, Gomong, Selaparang, Dasan Agung Baru, Selaparang, \\ Kota Mataram, Nusa Tenggara Barat 83115 \\ Email: ${ }^{1}$ badelah67@gmail.com, ${ }^{2}$ mahsunirn@gmail.com, \\ burhanuddinali@gmail.com
}

\begin{abstract}
This study aims to describe the type, and speech act strategy of teacher and student politeness in learning Indonesian in class VIII SMP Negeri 2 Sakra. The method used for data collection, namely observation, recording, and interviews. The results of the study show: (1) formalities between teachers and students always pay attention to the speech events when speaking; (2) speakers are always prejudiced towards the speech partners; (3) speakers are able to distinguish between conveying situations, namely serious situations and joking situations; (4) the types of teacher and student directive speech acts in Indonesian language learning in the classroom in the form of governing and the type of expressive speech acts in the form of forgiveness, praise, and criticism, both types of speech acts are predominantly conducted by teachers and students; (5) speakers are always introspective in order to know exactly what the partners say or use; (6) the principle of politeness and directive type of speech applied by teachers and students in learning Indonesian, including (1) maxim of wisdom; and (2) maxim of praise; (7) directive and expressive speech action strategies used by teachers and students in learning Indonesian, directly and indirectly.
\end{abstract}

Keywords: Pragmatics, speech acts, language politeness, language learning

\section{PENDAHULUAN}

Pembelajaran merupakan realitas komunikasi yang berlangsung dalam proses belajar mengajar di kelas atau interaksi kelas. Interaksi kelas terwujud dalam tindak tutur yang dilakukan oleh peserta tutur (guru dan siswa). Kegiatan bertutur di kelas akan berbeda dengan kegiatan bertutur di masyarakat secara alamiah. Di kelas terdapat tatakrama, sopan santun, dan budi pekerti yang merupakan aspek-aspek bahasa yang diekspresikan oleh sebuah komunikasi yang dilingkupi oleh berbagai konteks.

Dalam pembelajaran di kelas terjadi peristiwa tutur antara guru dengan siswa dan sulit dipisahkan dari kesantunan berbahasa. Sebab, pembelajaran bahasa Indonesia bertujuan membina dan mengembangkan pengetahuan, keterampilan, berkomunikasi yang diperlukan peserta didik dalam menempuh pendidikan, dan kecakapan di dunia kerja. Di sekolah, gurulah yang sangat berperan dalam membentuk kesantunan berbahasa bagi siswanya. Hal ini sejalan dengan pendapat Yule (2014:104) mengatakan 
bahwa kesantunan dalam suatu interaksi dapat didefinisikan sebagai alat yang digunakan untuk menunjukkan kesadaran tentang muka orang lain.

Kaitannya dengan penelitian yang relevan yang diteliti Nurul Masfufah (2010) mengkaji tentang bentuk kesantunan dan ketaksantunan dalam pembelajaran Bahasa Indonesia di kelas dan di luar kelas. Bentuk kesantunan ditemukan oleh peneliti, menggunakan kalimat deklaratif, interogatif, dan imperatif dalam bertutur baik di kelas maupun di luar kelas. Selain itu, penutur dengan mitra tutur selalu memperhatikan prinsip kesantunan yang dikemukakan Leech (1993) yaitu mengemukakan enam prinsip kesantunan; (1) makasim kearifan, (2) maksim kedermawanan, (3) maksim pujian, (4) maksim kerendahan hati, (5) maksim pemufakatan, dan (6) maksim simpati. Dengan menggunakan keenam maksim tersebut, kesantunan berbahasa guru dan siswa baik di kelas maupun di luar kelas dapat meningkat. Ahmad Fadilahtur Rahman (2017) mengkaji tentang kesantunan tutur guru dan siswa dalam interaksi belajar mengajar bahasa Indonesia di kelas, dengan menggunakan kalimat deklaratif, interogatif, dan imperatif dalam berttindak tutur memerintah. Dengan menggunakan kalimat deklaratif, interogatif, dan imperatif kesantunan guru dan siswa lebih halus dan harmonis. Kedua penelitian relevan ini, jika dikaitkan dengan penelitian yang dilakukan peneliti yaitu sama-sama mengkaji tentang kesantunan bertindak tutur guru dan siswa dalam pembelajaran bahasa Indonesia di kelas, dan dengan memperhatikan enam prinsip kesantunan yang dikemukakan Leech (1993).

Kesantunan berbahasa guru dan siswa di kelas VIII SMP Negeri 2 Sakra masih perlu diperhatikan, karena dipengaruhi oleh faktor lingkungan dan faktor sosial budaya serta kurang memperhatikan prinsip kesantunan dalam bertutur. Faktor lingkungan di dalam rumah tangga merupakan dasar penerapan kesantunan berbahasa. Oleh karena itu, hubungan orang tua dengan anak selalu terjaga dalam berkomunikasi atau bertindak tutur. Jadi, prinsip kesantunan wajib menyelesaikan masalah ini. Leech (1993:206-207) mengelompokkan prinsip kesantunan menjadi enam maksim yaitu, (1) maksim kearifan, (2) maksim kedermawanan, (3) maksim pujian, (4) maksim kerendahan hati, (5) maksim pemufakatan, dan (6) maksim simpati. Adapun rumusan masalah penelitian ini adalah:

1) Apa jenis tindak tutur kesantunan guru dan siswa dalam pembelajaran Bahasa Indonesia di kelas VIII SMP Negeri 2 Sakra?

2) Bagaimanakah strategi tindak tutur kesantunan guru dan siswa dalam pembelajaran Bahasa Indonesia di kelas VIII SMP Negeri 2 Sakra?

\section{KAJIAN TEORI}

\subsection{Pragmatik}

Pragmatik sebagai salah satu bidang ilmu linguitik, mengkhususkan pengkajian pada hubungan antara bahasa dan konteks tuturan. Pragmatik adalah kajian mengenai hubungan antara bahasa dengan konteks yang menjadi dasar dari penjelasan tentang pemahaman bahasa. Kajian mengenai sebuah bahasa yang mempertimbangkan tentang bagaimana cara penutur mengatur apa yang ingin mereka katakan yang disesuaikan dengan siapa yang diajak berbicara serta konteks situasi apa ingin disampaikan. Menurut Tarigan (2009:31) pragmatik merupakan telaah umum mengenai bagaimana caranya konteks mempengaruhi cara seseorang menafsirkan kalimat. Peranan konteks 
dalam penafsiran tampak pada kontribusinya dalam membatasi jarak perbedaan tafsiran terhadap tuturan dan menunjang keberhasilan pemberian tafsiran terhadap tuturan tersebut.

Pragmatik sangat terkait dengan konteks situasi sehingga di sini akan menjadi menarik jika kesantunan berbahasa guru dan siswa ketika mengajar di kelas dikaji menurut maksud penutur (guru) itu sendiri. Sebagaimana disampaikan Yule (2014:5) pragmatik adalah studi tentang makna yang disampaikan oleh penutur dan ditafsirkan pendengar. Maksud dari pendapat ini adalah penutur melakukan percakapan dengan lawan tutur dan membiarkan lawan tutur itu memberi makna apa yang dituturkan oleh si penutur. Oleh karena itu dalam kajian pragmatik ini si pendengar harus benar-benar mendengar tuturan yang disampaikan oleh penutur.

Teori pragmatik merupakan teori yang digunakan peneliti untuk menemukan makna tuturan yang dituturkan penutur kepada lawan tutur. Tuturan guru yang disampaikan kepada siswa ketika proses pembelajaran di kelas dikaji menurut maksud penutur (guru) itu sendiri. Tuturan direktif dan ekspresif yang digunakan guru dan siswa dalam pembelajaran Bahasa Indonesia di kelas akan menjadi tolok ukur dalam bertindak tutur. Dalam kajian pragmatik jenis tindak tutur ini yang menjadi fokus untuk diketahui maknanya.

\subsection{Komponen Tuturan}

\subsubsection{Situasi Tutur}

Sebagai salah satu cabang ilmu bahasa yang berkaitan langsung dengan peristiwa komunikasi, maka pragmatik tidak bisa dipisahkan dari konsep situasi tutur yang menyatakan bahwa, situasi tutur adalah situasi yang melahirkan tuturan. Hal tersebut berkaitan dengan adanya pendapat yang menyatakan bahwa tuturan merupakan akibat, sedangkan situasi merupakan penyebab terjadinya tuturan.

Situasi tutur sangat penting dalam kajian pragmatik, karena dengan adanya situasi tutur maksud dari sebuah tuturan dapat diidentifikasikan dan dipahami oleh mitra tuturnya. Sebuah tuturan dapat digunakan dengan tujuan untuk menyampaikan beberapa maksud atau sebaliknya. Terkait dengan tindak tutur kesantunan guru dan siswa dalam proses pembelajaran Bahasa Indonesia di kelas, yaitu makna dari tuturan disesuaikan dengan konteks situasi. Menurut Hymes (dalam Sumarsono, 2010:186) tindak tutur sebuah ujaran dianalisis dengan mempertanyakan konteks situasi yang melahirkan ujaran itu. Misalnya percakapan kepala sekolah dengan karyawan akan melahirkan situasi tutur yang berbeda dengan percakapan antara karyawan dengan karyawan lain.

\subsubsection{Peristiwa Tutur}

Dalam peristiwa tutur terdapat tindak tutur. Tindak tutur atau tindak ujar merupakan objek kajian pragmatik. Bentuk dan jenis tindak tutur ini dapat ditemukan dalam kehidupan sehari-hari, seperti berdiskusi, ceramah, tanya jawab, bercengkerama, dan sebagainya. Dengan kata lain segala aspek yang berkaitan dengan bahasa merupakan tindak tutur. Peristiwa tutur pada dasarnya merupakan rangkaian dan sejumlah tindak tutur yang terorganisasikan untuk mencapai suatu tujuan. Jika dalam peristiwa tutur lebih dilihat pada tujuan peristiwanya, tetapi dalam tindak tutur lebih dilihat pada makna atau arti tindakan dalam tuturannya. Tindak tutur dan peristiwa tutur 
merupakan dua gejala yang terdapat pada satu proses, yaitu proses komunikasi. Menurut Chaer dan Agustina (2014:47) mendefinisikan peristiwa tutur (speech event) adalah terjadinya atau berlangsungnya interaksi linguistik dalam satu bentuk ujaran atau lebih yang melibatkan dua pihak, yaitu penutur dan lawan tutur. dengan satu pokok tuturan, di dalam waktu, tempat, dan situasi tertentu. Jadi, interaksi belajar mengajar antara guru dengan siswa dalam pembelajaran bahasa Indonesia di kelas dengan menggunakan bahasa sebagai alat komunikasinya adalah sebuah peristiwa tutur.

\subsubsection{Konteks Tuturan}

Pragmatik memandang konteks sebagai pengetahuan bersama antara pembicara dan pendengar dan pengetahuan tersebut mengarah pada interpretasi suatu tuturan. Sejalan dengan pendapat Tarigan (2009:33) konteks diartikan sebagai setiap latar belkangan pengetahuan yang diperkirakan dimiliki dan disetujui bersama oleh penutur dan mitra tutur serta yang menunjang interpretasi mitra tutur terhadap apa yang dimaksud penutur dengan ucapan tertentu. Pengetahuan atau konteks tertentu dapat mengakibatkan manusia mengidentifikasi jenis-jenis tindak tutur yang berbeda. Konteks mempunyai fungsi yang penting dalam berbahasa. Konteks dapat menentukan makna dan maksud suatu ujaran. Konteks juga merupakan faktor luar yang menentukan fungsi komunikasi dari bahasa. Seseorang akan memahami sebuah tuturan apabila dapat memahami apa yang menjadi dasar tuturan tersebut. Dengan demikian, hal-hal seperti situasi, jarak, tempat, dan sebagainya dapat merupakan konteks pemakaian bahasa.

\subsection{Hakikat Tindak Tutur}

Tindak tutur adalah kemampuan seseorang individu melakukan tindakan ujaran yang mempunyai maksud tertentu sesuai dengan situasi tertentu. Menurut Ibrahim (1993:109) tidak tutur didefinisikan menurut fungsi psikologis dan sosial di luar wacana yang terjadi. Tindak tutur ini mencakup situasi psikologis dan situasi sosial. Tindak tutur lebih ditentukan pada arti tindakan dalam tuturannya. Hakikat tindak tutur adalah sesuatu yang dilakukan oleh penutur kepada mitra tutur dengan menggunakan bahasa sebagai alat komunikasi. Hal ini sesuai dengan fungsi bahasa sebagai alat komunikasi, yang bertujuan untuk merumuskan maksud dan melahirkan perasaan penutur.

\subsection{Proses Pembelajaran}

Proses pembelajaran merupakan upaya yang menciptakan suatu pelayanan terhadap kemampuan potensi, minat, bakat dan kebutuhan siswa yang beragam agar terjadi interaksi antara guru dengan siswa serta antara siswa dengan siswa. Berkaitan dengan usia siswa yang masih tergolong pendidikan dasar, yang kemampuan berbahasa siswa dalam mengucapkan bunyi-bunyi artikulasi atau kata-kata untuk mengekspresikan, mengatakan, serta menyampaikan pikiran, perasaan, dan gagasan sudah bisa menyesuaikan diri dengan kompetensi yang dimilki sehingga proses pembelajaran dapat berjalan lancar. Proses pembelajaran adalah proses yang di dalamnya terdapat kegiatan interaksi antara guru dengan siswa dan komunikasi timbal balik yang berlangsung dalam situasi edukatif untuk mencapai tujuan belajar. Dalam proses pembelajaran guru dan siswa merupakan dua komponen yang tidak bisa dipisahkan. Hal ini juga dikaitkan dengan keterampilan menyampaikan pesan secara 
lisan dalam bertuturan. Oleh karena itu, selama proses pembelajaran guru berinteraksi dan membimbing langsung siswa yang diajar. Menurut Undang-undang Sistem Pendidikan Nasional No. 20 Tahun 2003 menyatakan pembelajaran adalah proses interaksi peserta didik dengan pendidik dan sumber belajar pada suatu lingkungan belajar Pembelajaran sebagai proses belajar yang dibangun oleh guru untuk mengembangkan kreatifitas berpikir yang dapat meningkatkan kemampuan berpikir siswa, serta dapat meningkatkan kemampuan mengkonstruksikan pengetahuan baru sebagai upaya meningkatkan penguasaan yang baik terhadap materi pelajaran.

\section{METODE}

\subsection{Desain dan Jenis Penelitian}

Jenis penelitian ini adalah penelitian kualitatif. Artinya penelitian ini berusaha mencatat secara teliti semua fenomena kebahasaan sesuai dengan apa adanya. Penelitian ini bersifat deskriptif kualitatif, yakni berusaha untuk mengumpulkan informasi sesuai gejala, keadaan apa adanya pada saat penelitian dilakukan, serta dapat menggambarkan secara sistematis tentang tindak tutur kesantunan guru dan siswa dalam pembelajaran Bahasa Indonesia di kelas. Data diperoleh dari hasil observasi (pengamatan), dan wawancara. Hasil analisis data dapat berupa pemaparan mengenai situasi yang diteliti dan disajikan dalam bentuk uraian deskriptif.

Penelitian ini telah dilakukan di Kabupaten Lombok Timur Kecamatan Sakra. Adapun lokasi penelitian ini adalah di SMP Negeri 2 Sakra. Pemilihan lokasi ini ditentutukan atas pertimbangan bahwa tempat mengajar peneliti dan selama peneliti bertugas sebagai pengajar di sekolah ini beragam tindak tutur kesantunan yang peneliti temukan dalam penyampaian materi pembelajaran Bahasa Indonesia di kelas,. sehingga peneliti tertarik untuk meneliti. Di SMP Negeri 2 Sakra tergolong sekolah yang memiliki jumlah siswa dan guru yang banyak dan beraneka ragam latar belakang sosial budaya. Lokasi penelitian ini untuk mengamati secara langsung tindak tutur kesantunan guru dan siswa dalam pembelajaran Bahasa Indonesia di kelas VIII.

\subsection{Data dan Sumber Data}

Data penelitian ini adalah data tuturan guru dengan siswa, siswa dengan siswa yang berupa wujud kesantunan tindak direktif dan ekspresif guru dan siswa, strategi kesantunan tindak direktif dan ekspresif guru dan siswa, dan fungsi kesantunan tindak direktif dan ekspresif guru dan siswa dalam proses pembelajaran Bahasa Indonesia di kelas VIII SMP Negeri 2 Sakra.

Data tuturan guru dengan siswa, siswa dengan siswa diperoleh dari hasil pengamatan, perekaman, dan wawancara. Adapun Data yang diperoleh dari pengamatan (observasi), yaitu berupa data tentang tuturan guru dengan siswa dan siswa dengan siswa dalam proses interaksi pembelajaran Bahasa Indonesia di kelas. Data yang diperoleh dari perekaman interaksi belajar mengajar di kelas. Data tuturan guru dan siswa dalam proses pembelajaran bahasa Indonesia di kelas tersebut digambarkan tentang situasi dan komponen tindak tutur yang menyangkut karakteristik peserta tutur, topik tutur, latar, dan waktu tuturan. Data yang diperoleh dari wawancara yang dilakukan dengan guru secara formal untuk mengetahui titik terang bentuk tindak tutur 
kesantunana berbahasa Indonesia dalam berkomunikasi dengan siswa yang diterapkan berdasarkan data yang ingin diperoleh peneliti.

\subsection{Metode Pengumpulan Data}

\subsubsection{Observasi}

Observasi dalam penelitian ini bertujuan untuk mengamati secara langsung objek penelitian, jenis-jenis tindak tutur kesantunan, strategi tindak tutur kesantunan dan fungsi tindak tutur kesantunan guru dengan siswa, dan siswa dengan siswa, sehinga dapat memahami jenis, strategi, dan fungsi tindak tutur direktif dan ekspresif guru dengan siswa, siswa dengan siswa dalam proses pembelajaran Bahasa Indonesia di kelas.

Observasi dilakukan di SMP Negeri 2 Sakra secara langsung dengan menggunakan teknik simak, rekam, dan catat. Dengan teknik menyimak tuturan guru dan siswa saat proses pembelajaran Bahasa Indonesia berlangsung di kelas. Adapun teknik rekam yaitu merkekam tuturan guru dan siswa saat pembelajaran bahasa Indonesia di kelas akan ditranskripsikan kemudian dijadikan sebagai data utama, sedangkan teknik catat yaitu untuk mencatat tuturan guru dan siswa saat proses pembelajaran bahasa Indonesia di kelas yang kemungkinan tidak ada dalam rekaman. Pengamatan yang dilakukan sesuai dengan objek kajian tentang tuturan guru dan siswa dalam proses pembelajaran Bahasa Indonesia di kelas. Selain itu, mengamati peristiwa tutur, situasi, tuturan, dan konteks tuturan. Adapun aspek-aspek yang diamati dalam proses pembelajaran Bahasa indonesia di kelas, sebagai berikut.

- Jenis tindak tutur kesantuan guru dan siswa yang digunakan dalam proses pembelajaran Bahasa Indonesia di kelas.

- Strategi kesantunan yang digunakan guru dan siswa dalam proses pembelajaran Bahasa Indonesia di kelas.

\subsubsection{Wawancara}

Wawancara/interviw adalah merupakan pertemuan dua orang untuk bertukar informasi dan ide melalui tanya jawab, sehingga dapat dikonstruksikan makna dalam suatu topik tertentu Esterberg (2002) (dalam Sugiyono, 2017:231). Jadi dengan wawancara, peneliti akan mengetahui hal-hal yang lebih mendalam tentang partisipan dalam menginterpretasikan situasi dan fenomena yang terjadi. Bentuk wawancara yang digunakan dalam pengumpulan data adalah wawancara terstruktur, karena peneliti telah mengetahui informasi yang diperoleh narasumber. Oleh karena itu, dalam melakukan wawancara peneliti menyiapkan instrumen penelitian berupa pertanyaan-pertanyaan tertulis yang alternatif jawabannya pun telah disiapkan. Adapun jawaban dari informan yang diharapkan dapat berupa pendapat tentang tindak tutur kesantunan guru dan siswa yang digunnakan dalam proses pembelajaran Bahasa Indonesia di kelas.

\subsection{Penganalisisan Data}

Pada tahap ini peneliti berupaya meneliti langsung permasalah yang terkandung dalam data. Setelah data terkumpul lalu pembahasan dilakukan dengan metode padan ekstralingual. Mahsun (2017:123) padan merupakan kata yang bersinonim dengan kata banding dan sesuatu yang dibandingkan mengandung makna adanya keterhubungan 
sehingga padan di sini diartikan sebagai hal menghubungbandingkan, sedangkan ekstralingual tuturan yang berada di luar bahasa seperti hal-hal yang menyangkut makna, informasi, konteks, tuturan, dan lain-lain.

Jadi metode padan ekstralingual adalah metode analisis dengan cara menghubungbandingkan unsur-unsur yang bersifat lingual, baik yang terdapat dalam satu bahasa maupun dalam beberapa bahasa yang berbeda. Analisis penelitian ini, peneliti menghubungkan wujud bahasa dan isi tindak tutur pada guru dan siswa dalam proses pembelajaran Bahasa Indonesia di kelas yang sudah terkumpul dianalisis berdasarkan jenis tindak tutur dengan menggunakan teori dan kajian pragmatik.

Prosedur penelitian merupakan langkah-langkah penelitian dari awal sampai akhir. Adapun prosedur penelitian dapat diuraikan menjadi tiga, yaitu (1) tahap pengumpulan data, (2) tahap analisis, dan (3) tahap simpulan.

- Tahap pertama, adalah tahap pengumpulan data, Pada tahap pengumpulan data ini, data yang terdapat pada tindak tutur kesantunan guru dan siswa dalam proses pembelajaran Bahasa Indonesia di kelas yang sudah terkumpul dianalisis berdasarkan jenis tindak tutur kesantunan, strategi tindak tutur kesantunan, dan fungsi tindak tutur kesantunan dengan menggunakan teori dan kajian pragmatik.

- Tahap kedua, tahap analisis data, setelah data terkumpul berupa jenis, strategi, dan fungsi tindak tutur kesantunan pada tuturan guru dan siswa dalam proses pembelajaran Bahasa Indonesia di kelas dianalisis berupa jenis, strategi, dan fungsi tuturan guru dan siswa dalam proses pembelajaran bahasa Indonesia di kelas dengan menggunakan teori dan kajian pragmatik setelah itu dianalisis dengan mendeskripsikan jenis, strategi, dan fungsi tindak tutur kesantunan guru dan siswa dalam proses pembelajaran bahasa Indonesia di kelas.

- Tahap ketiga, yaitu tahap kesimpulan adalah tahap terakhir yang dilakukan peneliti, setelah analisis dilakukan oleh peneliti sehingga dapat diketahui hasilnya.

\section{HASIL DAN PEMBAHASAN}

\subsection{Jenis Tindak tutur Kesantunan}

\subsubsection{Jenis Tindak Tutur Kesantunan Direktif dalam Pembelajaran Bahasa Indonesia di Kelas}

Jenis tindak tutur direktif yang ditemukan dalam pembelajaran Bahasa Indonesia di kelas VIII SMP Negeri 2 Sakra, yaitu terdapat tiga tindak tutur yang paling banyak, yaitu memerintah, tindak tutur tersebut dapat dideskripsikan sebagai berikut.

\section{a. Tindak Tutur Direktif Guru kepada Siswa dalam Memerintah}

Tindak tutur direktif memerintah yaitu tindak tutur yang menyatakan tindakan. Tuturan yang disampaikan guru kepada siswa dalam menyampaikan perintah sebagai berikut.

[1] Guru:"Tolong, perhatikan yang membacakan hasil diskusi kelompok temanmu, kelompok yang lain menaggapi!" 
Data [1] dituturkan guru ketika memerintahkan siswa untuk memperhatikan temannya yang membacakan hasil diskusi kelompoknya di depan kelas.. Tuturan yang disampaikan guru dengan menggunakan kalimat imperatif, yaitu untuk memerintah siswa supaya memperhatikan temannya yang membacakan hasil diskusi kelompok dan kelompok lain menanggapi. Tuturan dengan kalimat imperatif kedenganaran lebih santun, yaitu dengan penanda kata "tolong" Dengan menggunakan kata "tolong" dapat dimaknai minta atau bantu (untuk menghaluskan perintah atau ajakan). Kata "tolong" menjadikan tuturan yang santun yang disampaikan kepada mitra tutur untuk memerintah.

\section{b.Tindak Tutur Direktif Siswa kepada Siswa dalam Memerintah}

Tindak tutur memerintah siswa kepada siswa lain tidak banyak ditemukan, dikarenakan masih kuatnya dominasi guru dalam proses pembelajaran. Deskripsi tuturan tersebut dapat dilihat dalam paparan data berikut ini.

[2]Guru :"Sebelum dilanjutkan, silakan yang belum selesai bicara diselesaikan bicaranya!"

Siswa :"Ssst, jangan bicara sendiri! Itu dengarkan Bu!"

Data [2] dituturkan oleh siswa kepada siswa lain sedang ribut padahal guru pada saat itu sedang menjelaskan materi pembelajaran. Tuturan siswa bermaksud memerintah temannya supaya jangan ribut karena akan mengganggu kegitan belajar mengajar. Tuturan yang disampaikan siswa tersebut tergolong santun, karena dilakukan pada konteks yang tepat, yaitu dituturkan ketika melihat temannya yang kurang hormat atau santun terhadap guru ketika guru sedang menjelaskan materi pembelajaran. Di samping itu, umur dan status yang relatif sama serta sudah akrab yang memungkinkan siswa untuk memerintah temannya.

\subsubsection{Jenis Tindak tutur Kesantunan Ekspresif dalam Pembelajaran Bahasa Indonesia di Kelas.}

Jenis tindak tutur ekspresif berbahasa Indonesia dalam pembelajaran bahasa Indonesia ditemukan dalam penelitian terdiri dari tiga, yaitu (1) tindak tutur memberi maaf, (2) memuji, dan (3) mengkritik. Ketiga tindak tutur ekspresif yang digunakan guru dan siswa dapat dideskripsikan sebagai berikut.

\section{a. Tindak Tutur Kesantunan Ekspresif Guru kepada Siswa dalam Memberi Maaf}

Tindak tutur ekspresif memberi maaf yaitu tindak tutur yang dilakukan oleh penutur kepada lawan tuturnya karena perasaan tidak enak penutur terhadap lawan tutur, karena telah merasa bersalah, mengganggu waktu lawan tutur. Berikut contoh tuturan dalam memberi maaf dan uraiannya.

[3] Guru :'Lain kali jangan diulangi lagi ya, ya sudah dimaafkan." 
Data [3] termasuk tuturan ekspresif guru kepada siswa,dapat dilihat dari kata "dimaafkan" Kata "dimaafkan" sebagai penanda bahwa penutur memberi maaf agar jangan diulangi lagi kesalahan yang dilakukan. Tuturan guru tersebut dianggap santun karena disampaikan dalam konteks yang tepat, yaitu di kelas, dan mitra tutur tidak merasa dipermalukan.

\section{b. Tindak Tutur Kesantunan Ekspresif Guru kepada Siswa dalam Memuji}

Tindak tutur guru pada saat memuji sebagai respon terhadap jawaban siswa Berikut disajikan tindak tutur ekspresif memuji beserta uraiannya.

[4] Guru :"Sebelum kita lanjutkan materi pembelajaran kita hari ini, masihkah ingat pelajaran kita pada minggu yang lalu?"

Siswa:"Struktur teks drama, Bu."

Guru :"Bagus sekali, masih ingat."

Data dialog [4] merupakan tuturan ekspresif guru kepada siswa, ketika guru mengingatkan pelajaran yang telah dipelajari sebelumnya. Tuturan merupakan memuji yang disampaikan guru kepada siswa, secara spontan terhadap jawaban siswa yang benar dengan kata "bagus sekali".dan memberikan apous berupa tepuk tangan. Pujian yang disampaikan guru tersebut termasuk santun karena membuat siswa senang dan merasa dihargai pendapatnya.

\section{c. Tindak Tutur Kesantunan Ekspresif Siswa kepada Siswa dalam Memuji}

Tindak tutur memuji yang disampaikan siswa sebagai respon terhadap pertanyaan guru atas tugas yang dilakukan oleh siswa lain. Berikut deskripsi tuturan memuji itu dipaparkan.

[5] Guru :"Bagaimana pementasan naskah dramanya?"

Siswa :"Suaranya, gesturnya, bagus, bu."

Data dialog [5] dituturkan oleh guru kepada siswa, ketika mengamati pementasan naskah drama. Tuturan siswa merupakan suatu pujian terhadap temannya yng telah mementaskan naskah drama dengan suara dan gestur yang bagus. Pujian siswa tersebut membuat siswa yang dipuji merasa senang, Dengan demikian, tuturan siswa kepada siswa lain termasuk tuturan yang santun karena disampaikan pada konteks situasi yang tepat, yaitu di kelas.

\section{d. Tindak Tutur Kesantunan Ekspresif Guru kepada Siswa dalam Mengkritik}

Tindak tutur ekspresif mengkritik yaitu tindak tutur yang dilakukan dengan maksud agar tuturannya dapat diartikan sebagai evaluasi tentang hal yang disebutkan dengan tuturan yang berupa kritikan.

[6] Guru :"Begitu saja, kok aduh. Pelajaran menulis naskah drama hebat, ya."

Data [6] dituturkan guru ketika siswa disuruh menulis naskah drama mengeluh. Kritikan yang disampaikan guru dimaksudkan agar siswa kalau disuruh jangan takut atau mengeluh. Tuturan yang disampaikan guru tersebut tidak akan mengancam muka 
siswa karena dilakukan dalam konteks di kelas. Dengan demikian tuturan guru dapat dikatakan santun.

\section{e. Tindak tutur Kesantunan Ekspresif Siswa kepada Siswa dalam Mengkritik}

Kritikan yang disampaikan siswa itu sebagai respon perilaku atau tuturan siswa lain dianggap kurang berkenan di hati guru. Berikut tindak tutur ekspresif mengkritik dipaparkan beserta uraiannya.

[7] Siswa :'Harap maklum Bu, belum biasa main drama."

Data [7] yang dituturkan siswa di atas, merupakan kritikan yang disampaikan sebagai respon terhadap pertanyaan guru atau prilaku siswa lain yang kurang berkenan di hati guru. Kritikan yang disampaikan siswa tersebut dapat dikatakan santun karena usia dan status yang relatif sama antara mereka untuk menkritik demi kebaikan siswa itu sendiri.

\subsubsection{Strategi Tindak Tutur Kesantunan}

\subsubsection{Strategi Tindak Tutur Kesantunan Direktif}

Strategi tindak tutur kesantunan berbahasa Indonesia dalam proses pembelajaran di kelas yang digunakan guru dan siswa berupa srtategi secara langsung dan secara tidak langsung.

\section{a. Strategi Tindak Tutur Kesantunan Direktif dalam Tuturan Memerintah Guru dan Siswa Secara Langsung}

Tindak tutur direktif terdiri atas, tindak tutur menyuruh, mennatang, dan bertanya.

\section{(1) Strategi Tindak Tutur Kesantuan Direktif Memerintah Secara Langsung}

\section{[1] Siswa :"Beri salam!"”}

Data [1] merupakan direktif menyuruh secara langsung. Tuturan ini diutarakan dengan maksud menyatakan jika ada guru datang dan masuk ke dalam kelas dengan mengucapkan salam. Penutur menyuruh mitra tutur (seluruh siswa) secara langsung yaitu dengan cara mengucapkan salam "Assalamualaikum Wr.Wb" agar guru merasa dihormati dan semua siswa di kelas mulai tenang ketika guru memasuki ruang kelas.

\section{(2) Strategi Tindak Tutur Kesantunan Direktif Memerintah Secara Tidak Langsung}

[2] Siswa :Semua sudah siap.

Data [2] termasuk tindak tutur direktif menyuruh secara tidak langsung tuturan ini dituturkan dengan maksud menyuruh temannya untuk tidak berisik dengan mengucapkan semua siap dengan menggunakan tuturan perintah yang digunakan untuk memerintah. 


\subsubsection{Strategi Tindak Tutur Kesantunan Ekspresif}

Tindak tutur ekspresif terdiri atas ekspresif memuji, memberi maaf, dan mengkritik.. Berikut disajikan tiga tindak tutur ekspresif secara langsung dan tidak langsung.

\section{a. Strategi Tindak Tutur Kesantunan Ekspresif Memuji \\ (1) Ekspresif Memuji Secara Langsung}

[6] Guru :"Ya, bagus sekali."

Data [6] termasuk tuturan langsung. Penutur secara langsung menuturkannya sesuai dengan makna yang ingin memuji mitra tutur (siswa).

\section{(2) Ekspresif Memuji Secara Tidak Langsung}

[7] Siswa :Selamat ya, hebat.

Data [7] termasuk tuturan tidak langsung. Tuturan tersebut termasuk tuturan ekspresif memuji, karena karena siswa memberikan selamat dan apresiasi berupa pujian secara tidak langsung terhadap temannya yang selesai presentasi hasil pekerjaannya.

\section{b. Strategi Tindak Tutur Kesantunan Ekspresif Memberi Maaf Guru dan Siswa Secara Langsung}

Ekspresif memberi maaf hanya ditemukan tuturan secara langsung. Berikut ekspresif memberi maaf beserta uraiannya.

[9] Siswa :"Tidak bawa bu, lupa."

Guru :"Jangan diulangi lagi, ya, dimaafkan."

Data dialog [9] termasuk tuturan secara langsung. Tuturan ini dapat dimaknai oleh mitra tutur (guru) yang sebagai pemberi maaf, karena penutur (siswa) tidak membawa tugasnya dan dimaafkan oleh guru.

\section{c. Strategi Tindak Tutur Kesantunan Ekspresif Mengkritik Guru dan Siswa Secara Langsung dan Secara Tidak Langsung}

\section{(1) Ekspresif Mengkritik Secara Langsung}

Ekspresif mengkritik guru dan siswa dapat dilihat pada paparan berikut.

[10] Siswa :"Maklum, bu. Belum biasa pentas."

Data [10] termasuk tuturan langsung. Tuturan ini dapat dimaknai oleh mitra tutur (guru dan siswa lain) sebagai kriktikan tentang cara pementasan drama yang kurang menarik dilihat oleh guru dan teman-teman di kelas. Tuturan tersebut digunakan untuk mengkritik teman yang sedang mementaskan drama di depan kelas. 


\section{(2) Ekspresif Mengkritik Secara Tidak Langsung \\ Ekspresif mengkritik guru dan siswa dapat disajikan berikut ini.}

[11] Guru :Anak-anak harap maklum, suasana kelas panas, jam sudah siang.

Data [11] termasuk tuturan tidak langsung. Tuturan ini dapat dimaknai oleh mitra tutur sebagai kritikan tuturan yang telah dituturkannya, tentang suasana kelas panas dan jam sudah siang. Tuturan tersebut dapat dimaknai oleh mitra tutur bahwa dilihat kondisi kelas yang sudah tak tahan lagi di dalam kelas. Penutur hanya memberitahu bahwa tuturan tersebut tentang suasana kelas yang tidak kondusif.

\subsection{PEMBAHASAN}

\subsubsection{Jenis Tindak Tutur Kesantunan Berbahasa Indonesia dalam Pembelajaran Bahasa Indonesia di Kelas VIII}

Jenis tindak tutur kesantunan guru dan siswa dalam pembelajaran bahasa Indonesia di kela, yaitu hanya membahas dua jenis tindak tutur yang paling banyak sering muncul (1) tindak tutur kesantunan direktif dalam menyampaikan memerintah, dan (2) tindak tutur ekspresif dalam menyampaikan, memberi maaf, memuji, dan mengkritik.

\subsubsection{Jenis Tindak Tutur Kesantunan Direktif Tuturan Guru dan Siswa dalam Memerintah}

Hasil penelitian ditemukan tindak tutur direktif dalam bentuk memerintah. Tindak tutur memerintah termasuk tuturan yang merugikan orang lain sehingga dianggap tuturan kurang santun. Namun tuturan memerintah bisa menjadi santun apabila dilakukan penutur mempunyai status lebih tinggi dari mitra tutur. Oleh karena itu, tingkat status sosial yang berbeda mempunyai kedudukan yang berbeda antar penutur dengan mitra tutur dalam konteks tuturan tertentu akan mempengaruhi kesantunan dalam memerintah. Kalimat perintah dalam bahasa Indonesia menjadi santun apabila ditandai dengan kata tolong, diharap, coba, sebaiknya, dan silakan.

Temuan penelitian ini sejalan dengan temuan yang dilakukan oleh Sadaruddin (2015) menemukan bahwa guru memerintah siswanya menggunakan kalimat interogatif, kalimat deklaratif, dan kalimat imperatif. Perintah dengan kalimat deklaratif hanya meminta pendengar saja tidak melakukan apa-apa atau hanya memberitahu, sedangkan perintah dengan kalimat interogatif isinya meminta pendengar memberi jawaban secara lisan, kalau kalimat imperatif isinya meminta agar pendengar memberi tanggapan berupa tindakan sesuai yang diminta (Chaer dan Agustina, 2014:50)

Hasil penelitian menunjukkan bahwa guru dalam memerintah siswanya menggunakan imperatif halus yang berkaitan dengan tugas yang dilakukan siswa ketika sedang membahas materi pelajaran. Kalimat imperatif halus yang digunakan oleh guru tersebut dianggap santun karena dilakukan dalam konteks pembelajaran di kelas.

Dari hasil penelitian ditemukan juga tindak tutur memerintah yang dilakukan siswa kepada siswa lain. Walaupun tuturan siswa kepada siswa lain tidak banyak, karena guru lebih mendominasi tuturan dalam proses pembelajaran. 


\subsubsection{Jenis Tindak Tutur Kesantunan Ekspresif Guru kepada Siswa dalam Menyampaikan Pujian \\ Dari hasil penelitian ditemukan tindak tutur memuji. Tuturan memuji} merupakan tuturan yang menyenangkan hati orang lain. Tindak tutur memuji ini sejalan dengan prinsip kesantunan, yaitu maksim pujian. Maksim pujian menyatakan kecamlah orang lain sedikit mungkin, dan pujilah orang lain sebanyak mungkin (Leech, 1993:206). Tindak tutur memuji guru kepada siswa merupakan respon terhadap jawaban siswa yang dianggab bagus. Tindak tutur memuji dilakukan oleh guru di kelas ingin menampilkan sebagai orang yang menghargai siswanya, merasakan bahwa pendapatnya dihargai oleh gurunya sehingga mendorong siswa lain untuk mengemukakan pendapat.

\subsubsection{Jenis Tindak Tutur Kesantunan Ekspresif Guru kepada Siswa dalam Memberi Maaf}

Dari hasil penelitian ditemukan tindak tutur memberi maaf. Tuturan memberi maaf merupakan tuturan menyenangkan hati orang lain. Tindak tutur memmberi maaf guru kepada siswa sebagai respon terhadap perilaku siswa yang pernah berbuat kurang berkenan di hati guru. Tindak tutur memberi maaf dilakukan oleh guru di kelas ingin menyadarkan siswanya atas kekeliruan yang dilakukan agar tidak boleh diulangi lagi.

\subsubsection{Jenis Tindak Tutur Kesantunan Ekspresif Tuturan Guru dan Siswa dalam Menyampaikan Kritikan}

Hasil penelitian ditemukan tindak tutur mengkritik. Kritikan merupakan ancaman terhadap muka mitra tutur. Namun, kritikan menjadi santun apabila dilakukan oleh orang yang mempunyai kekuasaan yang lebih tinggi untuk mengkritik. Dalam kritikan tersebut dapat menyadari kekurangan yang dimilkinya. Dari hasil penelitian ditemukan tindak tutur mengkritik guru kepada siswa. Kritik guru kepada siswa sebagai respon terhadap perilaku siswa yang dianggap oleh guru kurang baik, misalnya "Begitu saja, kok aduh". Guru dengan mengkritik secara halus lebih dapat diterima oleh siswa. Dapat dibuktikan bahwa setiap kritikan guru dapat membuat siswa berusaha memperbaiki kekurangannya dan mau memperhatikan guru tersebut.

\subsubsection{Strategi Tindak Tutur Kesantunan Berbahasa Indonesia dalam Pembelajaran Bahasa Indonesia di Kelas VIII}

Jenis tindak tutur kesantunan guru dan siswa dalam pembelajaran bahasa Indonesia di kelas, yaitu hanya membahas dua strategi tindak tutur yang paling sering digunakan guru dan siswa, yaitu strategi secara langsung dan secara tidak langsung.

\subsubsection{Strategi Tindak Tutur Kesantunan Direktif Guru dengan Siswa dan Siswa dengan Siswa dalam Memerintah}

Dari hasil penelitian ditemukan bahwa guru dalam memerintah siswa menggunakan strategi tuturan langsung. Strategi tuturan langsung yang digunakan oleh guru untuk memerintahkan siswa dalam melaksanakan tugas, dengan menggunakan penanda kata tolong, coba, diharap, silakan. Strategi tuturan langsung yang digunakan guru dalam memerintah siswa merupakan tuturan yang santun, karena usia, status guru 
yang lebih tinggi, jarak sosial, dan konteks tuturan di kelas memungkinkaan guru untuk memerintah secara langsung.

\subsubsection{Strategi Tindak Tutur Kesantunan Ekspresif Guru dengan Siswa dalam Memberi Maaf. \\ Dari hasil penelitian ditemukan tindak tutur memberi maaf guru kepada siswa} karena siswa merasa pernah melakukan sesuatu yang kurang berkenan di hati guru. sehingga guru memaafkan. Strategi yang digunakan guru dalam memberi maaf kepada siswanya, yaitu srtategi secara langsung. Strategi secara langsung dilakukan saat proses pembelajaran berlangsung di kelas.

\subsubsection{Strategi Tindak Tutur Kesantunan Ekspresif Guru kepada Siswa dalam Memuji}

Dari hasil penelitian ditemukan tindak tutur memuji siswa oleh guru karena siswa telah mengerjakan tugas dengan benar. Tindak tutur memuji ini dilakukan oleh guru karena guru merasa bangga terhadap siswa yang bisa melakukan pekerjaan dengan baik. Dengan tindak tutur memuji guru ini pula menjadi motivasi bagi siswa lain.

\section{SIMPULAN DAN SARAN}

Berdasarkan penganalisisan data tentang jenis, strategi, dan fungsi tindak tutur kesantunan guru dan siswa dalam pembelajaran Bahasa Indonesia di kelas, disimpulkan:

\section{1) Jenis tindak tutur kesantunan guru dan siswa dalam pembelajaran Bahasa indonesia di kelas}

Jenis tindak tutur yang digunakan guru dan siswa di kelas VIII SMP Negeri 2 Sakra yang paling banyak adalah tindak tutur direktif dan tindak tutur ekspresif. Adapun tindak tutur direktif mencakup: memerintah, sedangkan tindak tutur ekspresif meliputi: memberi maaf, memuji, dan mengkritik.

\section{2) Strategi tindak tutur kesantunan guru dan siswa dalam pembelajaran Bahasa Indonesia di kelas}

Strategi tindak tutur kesantunan guru dan siswa dalam pembelajaran Bahasa Indonesia di kelas VIII SMP Negeri 2 Sakra yang digunakan strategi langsung dan strategi tidak langsung. Strategi tindak tutur direktif memerintah hanya menggunakan strategi secara langsung, direktif. Strategi tindak tutur ekspresif memberi maaf, ditemukan hanya menggunakan strategi secara langsung, ekspresif memuji, dan mengkritik menggunakan strategi secara langsung dan secara tidak langsung.

Untuk memperbaiki kelemahan hasil penelitian, berikut ini dikemukakan beberapa saran:

1) Sebaiknya guru dan siswa harus memperhatikan tindak tutur kesantunan berbahasa dalam pembelajaran Bahasa Indonesia di kelas. Dengan perhatian yang sungguhsungguh terhadap tindak tutur kesantunan berbahasa, maka komunikasi antara guru dengan siswa, siswa dengan siswa dapat lebih bermakna.

2) Para peneliti berikutnya yang tertarik pada kajian ini, dipersilakan meneliti tindak tutur kesantunan berbahasa baik jenis, strategi, secara lebih mendalam. 


\section{DAFTAR PUSTAKA}

Chaer, Abdul. Dan Leonie Agustin. 2014. Sosiolingiustik Perkenalan Awal. Jakarta: Rineka Cipta.

Ibrahim, Abd. Syukur. 1993. Kajian Tindak Tutur. Surabaya: Usaha Nasional.

Leech, Geoffery. 1993. The Principles of Pragmatics. Alihbahasa. M.D.D. Oka Prinsipprinsip Pragmatik. Jakarta: Universitas Indonesia.

Mahsun. 2017. Metode Penelitian Bahasa Tahapan, Strategi, Metode, dan Tekniknya. Jakarta: RajaGrafindo Persada.

Masfufah, Nurul. 2010. "Kesantunan Bentuk Tuturan di Lingkungan SMA Negeri 1 Surakarta”. Program Magister Bahasa Indonesia. Universitas Sebelas Maret.

Rahman, Ahmad Fadilahtur Rahman. 2017. "Kesantunan Tutur Guru Dalam Interaksi Pembelajaran Bahasa Indonesia di Kelas VII SMP Negeri 1 Situbondo". Program Magister Bahasa Indonesia. Universitas Negeri Malang.

Sumarsono. 2012. Sosiolinguistik. Yogyakarta: Sabda.

Tarigan, Henry Guntur. Pengajaran Pragmatik. Bandung: Angkasa.

Yule, George. 2014. Pragmatik. Yogyakarta: Pustaka Pelajar Offset. 
LINGUA, Vol. 16, No. 2, September 2019

p ISSN: 1979 9411; e -ISSN: 2442 238X

Http://lingua.soloclcs.org; Email: presslingua@gmail.com

Center of Language and Cultural Studies, Surakarta, Indonesia

Badelah; Mahsun \& Burhanuddin. 2019. Tindak Tutur Kesantunan Guru dan Siswa

dalam Pembelajaran Bahasa Indonesia di SMP Negeri 3 Sakra: Tinjauan Pragmatik.

Lingua (2019), 16(2): 219-234. Http://doi.org/10.30957/lingua.v16i2.269. 